\title{
Financial Satisfaction of Islamic Investing: The Role of Religiosity and Financial Knowledge
}

\author{
R D A Parmitasari ${ }^{1}$, L Bulutoding $^{2}$, Z Alwi $^{3}$ \\ Department of Management, Faculty of Islamic Economics and Business, UIN Alauddin Makassar ${ }^{1}$ \\ Department of Accounting, Faculty of Islamic Economics and Business, UIN Alauddin Makassar ${ }^{2}$ \\ Department of Judicial and Family Law, Faculty of Shariah and Law, UIN Alauddin Makassar ${ }^{3}$ \\ \{rparmitasari@uin-alauddin.ac.id ${ }^{1}$, lince.bulutoding@uin-alauddin.ac.id ${ }^{2}$,zulfahmi.alwi@uin-alauddin.ac.id ${ }^{3}$ \}
}

\begin{abstract}
Islamic investment has arisen as an excellent choice for investors to invest in following their beliefs. Religiosity and financial knowledge as part of personal factors were claimed to stimulus investors in investment decision-making. Ultimately, Islamic investing contributes to the achievement of financial satisfaction. This rare topic is compelling to be discussed in relation to capital market behavior and financial satisfaction. The paper aimed to explore the role of religiosity and financial knowledge of Islamic investing and its impact on financial satisfaction. Data was collected from the questionnaire and analyzed quantitatively. The sample was 227 respondents and structural equation modeling was used to explore the relationship of each variable in this paper. The result showed that religiosity and financial knowledge played a role in Islamic investing. In terms of financial satisfaction, financial knowledge directly influenced financial satisfaction while religiosity did not. However, both religiosity and financial knowledge affected financial satisfaction through Islamic investing. The result implicitly stated that Islamic investing was a good mediator for religiosity and financial knowledge in achieving financial satisfaction.
\end{abstract}

Keywords: Religiosity, Financial Knowledge, Investor Behaviors, and Financial Satisfaction

\section{Introduction}

Islamic capital market has developed rapidly and worldwide in the past 20 years. Islamic capital market has reached almost all regions of the world from Southeast Asia to Europe, thus it has made the Islamic capital market an international market for investment and fundraising activities. With that role, the Islamic capital market becomes an important part of the Islamic financial system that cannot be denied. The existence of Islamic capital markets encourages the mobilization of resources efficiently and optimizes the allocation of funds that complements the role of financial intermediaries as institutions in the investment process [1].The development of the Islamic capital market is still moving along with the opportunities provided in terms of investment and the movement of funds. According to Thompson Reuters, assets in the industry in 2017 reached USD 2.4 trillion and Sukuk contributed $17 \%$ and mutual funds contributed $4 \%$ [2]. It shows the existence of the Islamic capital market as the second-largest contribution to the global Islamic financial system.

The important role of the Islamic capital market also has an impact on Indonesia as one of the countries with the largest Muslim population in the world. It can be seen from the recognition of the Islamic capital market in Indonesia globally. This can be proven from the award received in 2018 as the best emerging Islamic capital market of the year 2018 [3]. One of the sharia-capital market products in Indonesia that has a strong appeal is Sukuk. Sukuk is an important tool in the search for international funds and investment activities with significant cross-regional cash flows [4]. Indonesia has become one of the 3 largest countries in the development of state Sukuk after Malaysia and Saudi Arabia [2]. Meanwhile, Indonesia ranks 7th globally for corporate Sukuk [5]. The Sharia capital market in Indonesia already has more than $50 \%$ of Sharia shares listed on the Indonesian stock exchange [6]. In 2018, the Islamic capital market in Indonesia already has 3 stock indices, namely the Jakarta Islamic Index (JII), the Indonesian Sharia Stock Index (ISSI) and the Jakarta Islamic Index 70 (JII70) [3].

Investors, through their investment behavior, are one of the keys to developing the Islamic capital market. Dorsey (2004)confirmed that human behavior is an important element in the capital market. The importance of investor behavior is seen in its role in utilizing the Islamic capital market as a place to invest for certain financial purposes. Previous research confirms that investor behavior in the capital market is not always in harmony with rationality and even refers to psychology in understanding the behavior [8]-[10]. This emphasizes that investors as individuals have different characteristics and thoughts so that they are more influenced by the factors that shape themselves or are known as psychological factors. The existence of new theories about investor behavior is needed by including new theoretical components that have an emotional character, a comprehensive and open-minded market approach [11], [12]. The emergence of behavioral finance theory shows a view that pays 
more attention to the uniqueness and characteristics of each individual who becomes an investor in both Islamic and conventional capital markets. Behavioral finance theory is the study of the influence of psychology on the behavior of financial practitioners and their effects on the market [13] and explains how psychology influences financial decision making on financial markets with an open-minded financial approach [11], [12], [14].

Individuals have financial goals to be achieved in investing. These financial goals are achieved through actions that are reflected in investor behavior, most likely leading to the financial satisfaction of the individual investor. The behavior itself is not an outcome but it directs and contributes to the results [15]. Henceforth, investor behavior is a tool used by individual investors to achieve their financial goals and ultimately will provide financial satisfaction to these investors. Financial problems are known as the main determinant of satisfaction [16]. The importance of achieving financial satisfaction is evident from its role as one of the factors supporting the realization of individual happiness. Financial satisfaction for individuals is seen as a trigger in increasing individual satisfaction and life satisfaction [17]. Previous studies have revealed the importance of financial satisfaction for the lives of individuals. The study of financial satisfaction and the factors that contribute to it is important in increasing individual financial happiness [18]-[21].

One factor that can influence investor behavior and financial satisfaction is religiosity. Previous studies revealed that religiosity drives behavior (Guiso, Sapienza, \& Zingales, 2013; Klein, Turk, \& Weill, 2017; Kumar, Page, \& Spalt, 2011; Mansour \& Jlassi, 2014; Van Praag, Romanov, \& Ferrer-i-carbonell, 2010)and religiosity also gives meaning to individual satisfaction [23], [25], [28], [29]. Religion is a guide for individuals in running life. Each individual will have different levels of religiosity as a reflection of individuals in obeying their respective religious orders. Thus, individuals will respond differently to religious beliefs and behave in accordance with the beliefs they hold. Research by Seyyed, Abraham, \& Al-hajji (2005), Bialkowski, Bohl, Kaufmann, \& Wisniewski (2013)and Klein et al. (2017)show there is a tendency that religiosity influences individual behavior in investing especially in religious periods (Ramadhan).

Another factor that can affect both investor behavior and financial satisfaction is financial knowledge. Financial knowledge is formed from within individuals and the environment that surrounds it. Previous studies have shown that financial knowledge has a role in behavior (Jacobs-lawson \& Hershey, 2005; Robb, 2011; Robb \& Woodyard, 2011)and financial satisfaction(Parrotta \& Johnson, 1998; Robb \& Sharpe, 2009; Robb \& Woodyard, 2011). Every individual has financial knowledge, but each individual has a different level of financial knowledge and will influence decision making in behavior in capital market investments. There are various types of financial knowledge from capital market investors and different financial knowledge will encourage investors to behave differently in utilizing online or offline investment facilities [39].

Based on the explanation above, this study will examine the financial satisfaction of investing in Islamic capital markets by considering the role of religiosity and financial knowledge. The study focuses on the role of religiosity and financial knowledge on the financial satisfaction of Islamic capital market investors and the role of religiosity and financial knowledge on investor behavior of the Islamic capital market. Furthermore, this study will also explain whether religiosity and financial knowledge can be a driving factor in achieving financial satisfaction through the investor behavior of the Islamic capital market.

\section{Method}

This research was explanatory research. It could be seen from the research problems that have been raised previously. This quantitative approach research had 4 research variables. From these 4 variables, 2 variables were independent variables namely religiosity and financial knowledge. The other two variables, investor behavior, and financial satisfaction were the dependent variables. Investor behavior in this study was a mediating variable linking religiosity and financial knowledge to financial satisfaction.

This study was conducted by taking a location in South Sulawesi. Survey data collection was conducted in early January 2018 until October 2018 on securities companies and the Indonesia Stock Exchange, the Stock Exchange Corner located at local universities. The population was individual investors in the Islamic capital market in South Sulawesi until October 2018. The sample was chosen by incidental sampling. The samples collected in this study were 227 respondents. Data collection was carried out using the questionnaire, observation and interview methods of the respondents. In this study, the data analysis technique was structural equation modeling (SEM) with Smart PLS. 


\section{Result and Discussion}

Figure 1. Structural Model

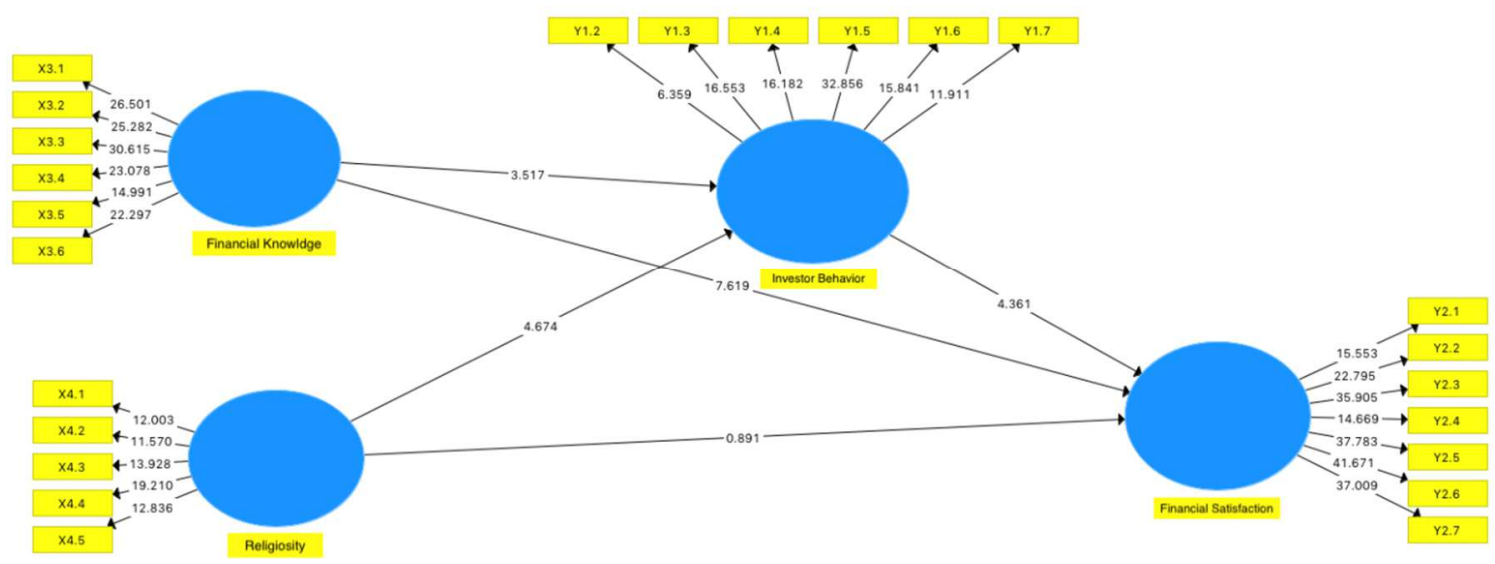

Source: Data Processed, 2019

\section{Hypothesis testing}

Based on the results, it can be seen from the five indirect relationships that only one relationship proved to be insignificant. The insignificant direct relationship is the effect of religiosity on financial satisfaction. Meanwhile, the other four direct relationships proved to be significant at the $99 \%$ confidence level. Meanwhile, the two hypotheses of indirect relationships are proven to be significant with a $99 \%$ confidence level.

\section{The Influence of Religiosity on Financial Satisfaction}

The results showed that the effect of religiosity on financial satisfaction was not significant. The financial satisfaction of Islamic capital market investors is not influenced by the religiosity of the investors. This result is contrary to research by [22], Krause (2003)and Van Praag et al. (2010) which states that a person's level of religiosity has an impact on a person's financial satisfaction. The absence of the role of religiosity in financial satisfaction directly shows that individual investor perceives financial satisfaction subjectively and only focuses on achieving financial goals that lead the investor to satisfaction and happiness in their lives. Financial satisfaction has a close relationship in realizing satisfaction and happiness in the lives of individuals (Diener \& Diener, 2002; Falahati et al., 2012; Van Praag, 2004).

Religiosity is not a prediction in the financial satisfaction of Islamic capital market investors because religiosity has allegedly blended into the individual. The integration of religiosity into individuals can be considered as part of the assets owned and formed within the individual investors' life. In individuals as investors, when individuals are moved to achieve financial satisfaction, individuals will use all that is in themselves called capital or assets so that it is not implied as a separate part. This is consistent with the subjective well-being theory (SWB) that one of the capital that can be owned by individuals is human capital that can be formed from the attitudes and experiences of individuals [43]. The human capital that is formed in individuals is driven by what they experience and becomes continuous learning. Correspondently, life cycle planning theory stated that individuals will modify what they produce and convert it into something that is most desired by the individual [44].

\section{The Impact of Religiosity on Investor Behavior}

Based on the results of hypothesis testing, religiosity affects the behavior of Islamic capital market investors positively and significantly. A validated positive relationship between religiosity and sharia-capital market investor behavior indicates that sharia-capital market investors in investing are still guided by what is believed in their religion. The results of this study are in line with previous research showing that religiosity has a role in encouraging investor behavior (Guiso et al., 2013; Klein et al., 2017; Kumar et al., 2011; Mansour \& Jlassi, 2014; Van Praag et al., 2010).

Religiosity acts as a good prediction in the behavior of Islamic capital market investors giving a signal that Islamic capital market investors still consider the value of their religious beliefs and will act in accordance with the religious principles they believe. Investors will make investment decisions in accordance with the values, principles, and morals adopted and one of the factors that provide values, principles, and morals to investors is a religion [45]. This shows that investors as individuals have a bias in behavior. Research shows that investors as investors' behavior as individuals have different types with different types of bias [46]. The behavioral bias shown by investors as individuals shows the existence of irrationality that prioritizes psychological factors in 
making a decision. This is in line with behavioral finance which says that the behavior of economic and financial actors in terms of psychology by referring to cognitive and behavior can explain the reasons for irrational decision making in the capital market(Ezama et al., 2014; Lovric, Kaymak, \& Spronk, 2008; Shafi, 2014).

\section{The influence of Financial Knowledge on Financial Satisfaction}

According to the results of hypothesis testing, financial knowledge affects financial satisfaction positively and significantly. This shows that financial knowledge is a good prediction for financial satisfaction. The financial satisfaction of Islamic capital market investors can be achieved with the existence of financial knowledge. The results of this study are supported by previous research which shows that financial satisfaction is influenced by financial knowledge (Joo \& Grable, 2004; Loibl \& Hira, 2005; Robb \& Sharpe, 2009; Robb \& Woodyard, 2011).

The existence of financial knowledge can make changes in the mindset and perceptions of an individual in the financial. In SWB, individuals can achieve financial satisfaction by using the bottom-up factors approach. The bottom-up factors theory mentioned that financial satisfaction can be influenced by factors that come from the internal and external of individuals [50]. Financial knowledge as a factor is obtained by individuals internally and externally. Changes in individual perceptions of things in the future would alter perceptions of financial satisfaction. Individual perceptions of the future affect the way of viewing and individual perceptions of financial satisfaction (Mammen, Helmick, \& Metzen, 1983). In this context, individuals utilize the financial knowledge they already know and apply it to achieve their wants in terms of finance and financial conditions. Hira \& Mugenda (1998)confirms that the best predictions of financial satisfaction are more directed to the desire for financial improvement and changes in financial conditions that individuals want to experience.

\section{The Influence of Financial Knowledge on Investor Behavior}

Financial knowledge is an incentive for investors to invest in the Islamic capital market. The presence of financial knowledge in individuals as investors motivates and ultimately manages to make investors invest in the Islamic capital market. This evidence is also supported by previous studies showing similar results that financial satisfaction is influenced by financial knowledge (Jacobs-lawson \& Hershey, 2005; Robb \& Sharpe, 2009; Robb \& Woodyard, 2011).

Financial knowledge is knowledge about finance that is obtained by individuals from their environment and blends in expertise and knowledge in individuals to change individual perceptions about finance. An individual's financial expertise and competence results from his understanding and mastery of that individual's financial knowledge [53]. Thus, investor behavior comes from the driving factors of financial knowledge that can come from within individuals as a learning process and knowledge gained from the environment around individuals. Based on Bandura (1971,1985), an individual's behavior is influenced by what is inherent in him or herself and the circumstances or situations that surround him or the environment. Financial knowledge has a close relationship with knowledge about financial practices and one of them is about investment [56]. Thus, financial knowledge opens investors 'insights and thoughts in investing which psychologically influences investors' decisions in investing.

\section{The Impact of Investor Behavior on Financial Satisfaction}

From the results of the study, investor behavior positively and significantly affects the financial satisfaction of Islamic capital market investors. When Islamic capital market investors make investments, the financial satisfaction of Islamic capital market investors can be achieved. The relationship between investor behavior and financial satisfaction is also supported by previous literature (Falahati et al., 2012; Parmitasari, 2018; Xiao et al., 2013).

Investor behavior is indeed not as the final result but only as an important factor in the final achievement process, namely financial satisfaction. Individuals have a role in determining the achievement of financial satisfaction through the financial behavior they do [35]. The final result is the achievement of financial goals which are demonstrated through the fulfillment of financial satisfaction and overall life satisfaction. Investors in investing also hope to get expressive and emotional benefits from their investments (Statman, 2004). Investor behavior is carried out to accommodate the financial plan and will produce a sense of satisfaction with the achievement of these financial goals. SWB theory says that satisfaction can be subjectively expressed in the form of financial satisfaction [20], [57]. Therefore, financial satisfaction that comes from the individual subjectivity can only be achieved by the role of the individual [45]. 


\section{Mediating Effect of Investor Behavior towards Relationship between Religiosity and Financial Satisfaction}

Investor behavior is a good mediation between the relationship between religiosity and financial satisfaction. This result is different from previous results, which show if the direct relationship between religiosity and financial satisfaction is not significant. The role of investor behavior as a mediation between the relationship of religiosity and financial satisfaction is still rare in the financial literature. Research by Dale (2015)found the mediating's role of individual behavior towards religiosity and financial satisfaction.

Individual religious beliefs will influence the way of individual thinking and individual decision making. This applies equally especially in the financial sector. In decision making, the religion and the level of individual religiosity will provide guidance in the form of values and principles held by individuals. Pargament (2002) said that religiosity can bring many benefits to individuals who believe in a religion which can be seen as motivation that gives value to actions that bring individuals to satisfaction in their lives. Individuals will invest according to their values and get life satisfaction without having to set aside these values [45].

The role of religiosity in investor behavior and financial satisfaction could be seen from the commitment to the fulfillment of sharia principles in the Islamic capital market. In the Islamic capital market, the investment must go through a screening and purification process. Individual investors in this research commit in the Islamic capital market and expect to obtain financial satisfaction without having to put aside their religiosity. This is known as faith-consistent investing. Girard \& Hassan (2008)mentioned that investors will integrate their religious principles with strategies in investing by considering risks, returns, and investment performance.

\section{The Influence of Financial Knowledge on Financial Satisfaction through Investor Behavior}

In achieving financial satisfaction, Islamic capital market investors have good predictions, namely financial knowledge and investor behavior. The results also showed that investor behavior is a good mediation between financial knowledge and financial satisfaction of Islamic capital market investors. This finding is in line with the results of research conducted by Arifin (2018).

When individuals have adequate financial knowledge, individuals will be motivated to behave in achieving financial success. When the desire is achieved then the individual has financial satisfaction. Joo (2008) said that financial knowledge is one element in encouraging individuals to achieve financial wellness that is in line with financial satisfaction and financial behavior. The motivation for achieving financial goals will be even greater along with the increase in financial knowledge of Islamic capital market investors and ultimately will help investors in obtaining financial satisfaction. Research by Joo \& Grable (2004)and Loibl \& Hira (2005) indicated that financial behavior with higher financial knowledge will be associated with an increase in financial satisfaction.

When individuals have financial knowledge, individuals will make adjustments and encourage individuals to act according to what they know. Curiosity arising from the existence of financial knowledge about the Islamic capital market drives individuals to achieve their financial goals and ends with their financial satisfaction. Individuals will try to get the desired financial satisfaction by relying on their financial knowledge and trying to get financial satisfaction by manifesting in the form of investing. Ali, Zani, \& Kasim (2014)stated that the higher level of financial knowledge has a positive influence on financial behavior that increases financial capability and contributes to financial satisfaction. Similar to adaptation level theory, individual satisfaction will depend on change and how individuals respond, manage it and adapt to changes according to themselves [20].

\section{Conclusion}

This research found that there was a relationship between religiosity and financial knowledge towards investor behavior of the Islamic capital market in pursuing financial satisfaction. Religiosity and financial knowledge played a role in Islamic investing. Financial knowledge directly affected financial satisfaction while religiosity did not. Furthermore, religiosity and financial knowledge influenced financial satisfaction through Islamic investing. The result also indicated that Islamic Investing was a good mediator for religiosity and financial knowledge in achieving financial satisfaction.

\section{References}

[1] Z. A. Azis, "Zeti Akhtar Aziz: Islamic finance in a challenging economy - moving forward," Kuala Lumpur, 2012.

[2] Indonesian Ministry of National Development Planning, "Indonesia Ekonomi Syariah Islamic Economic Masterplan Indonesia 2019-2024,” 2019.

[3] Islamic Finance News, "IFN Indonesia Report 2018," 2018.

[4] F. di Mauro et al., "ISLAMIC FINANCE IN EUROPE ISLAMIC FINANCE IN EUROPE,” 2013.

[5] Islamic Financial Services Board, "Islamic Financial Services Industry Stability Report," 2018. 
[6] Otoritas Jasa Keuangan, "Syariah 2015 - 2019,” 2019.

[7] W. Dorsey, Behavioral Trading Take-Aways. USA: Thomson Texere, 2004.

[8] A. Murgea, "Investor's Psychology Cycle On The Romanian Capital Market," Analele Univ. “Alexandru Ioan Cuza”Iaşi-Ştiinţe Econ., vol. 55, 2008.

[9] M. Sehgal and D. . Singh, "Psychology Of Investors Based On Value And Life," Int. J. Transform. Bus. Manag., vol. 2, no. 2, 2012.

[10] K. C. Phan and J. Zhou, "Vietnamese Individual Investors ' Behavior in the Stock Market: An Exploratory Study,” Res. J. Soc. Sci. Manag., vol. 3, no. April, pp. 1-9, 2014.

[11] A. Konstantinidis, A. Katarachia, G. Borovas, and M. E. Voutsa, "From Efficient Market Hypothesis To Behavioral Finance : Can Behavioral Finance Be The New Dominant Model For Investing?," Sci. Bull. Sci., vol. 11, no. 2, pp. 16-26, 2012.

[12] R. Thaler, "Mental Accounting and Consumer Choice," Mark. Sci., vol. 4, no. 3, pp. 199-214, 1985.

[13] M. Sewell, Behavioural Finance, vol. 2007, no. February 2007. University of Cambridge, 2010.

[14] H. Shefrin, Beyond Greed and Fear. Oxford University Press, 2002.

[15] M. Fishbein and I. Ajzen, Belief, Attitude, Intention and Behavior: An Introduction To Theory and Research. Addison Wesley Publishing Company, 1975.

[16] L. Falahati, M. F. Sabri, and L. H. J. Paim, "Assessment a Model of Financial Satisfaction Predictors: Examining the Mediate Effect of Financial Behaviour and Financial Strain," World Appl. Sci. J., vol. 20, no. 2, pp. 190-197, 2012.

[17] R. D. A. Parmitasari, "Gender dan Kepuasan Keuangan Investor Pasar Modal di Sulawesi Selatan," Patri Artha Manaj. J., vol. 1, no. 2, pp. 247-266, 2017.

[18] J. J. Xiao, C. Chen, and F. Chen, "Consumer Financial Capability and Financial Satisfaction," Soc. Indic. Res., 2013.

[19] J. J. Xiao, C. Tang, and S. Shim, "Acting for Happiness: Financial Behavior and Life Satisfaction of College Students,” Soc. Indic. Res., vol. 92, pp. 53-68, May 2008.

[20] E. V. Toscano, V. A. Amestoy, and R. S. Del-rosal, "Building Financial Satisfaction,” 2004.

[21] S. Joo and J. E. Grable, "An Exploratory Framework of the Determinants of Financial Satisfaction," $J$. Fam. Econ. Issues, vol. 25, no. 1, 2004.

[22] K. I. Pargament, "Is Religion Nothing But ...? Explaining Religion Versus Explaining Religion Away," Psychol. Inq., vol. 13, no. December 2014, pp. 229-244, 2002.

[23] B. M. S. Van Praag, D. Romanov, and A. Ferrer-i-carbonell, "Happiness and financial satisfaction in Israel : Effects of religiosity, ethnicity, and war," J. Econ. Psychol., vol. 31, no. 6, pp. 1008-1020, 2010 .

[24] W. Mansour and M. Jlassi, "The Effect of Religion on Financial and Investing Decisions," in Investor Behavior: The Psychology of Financial Planning and Investing, no. 2011, K. Baker and V. Ricciardi, Eds. John Wiley \& Sons, Inc., 2014, pp. 135-151.

[25] P. Klein, R. Turk, and L. Weill, "Religiosity vs . Well-Being Effects on Investor Behavior," J. Econ. Behav. Organ., 2017.

[26] A. Kumar, J. Page, and O. Spalt, "Religious Beliefs , Gambling Attitudes , and Financial Market Outcomes," J. financ. econ., vol. 102, no. 3, 2011.

[27] L. Guiso, P. Sapienza, and L. Zingales, "The Determinants of Attitudes toward Strategic Default on Mortgages," J. Finance, vol. LXVIII, no. 4, 2013.

[28] N. Krause and E. Bastida, "Financial strain, religious involvement, and life satisfaction among older Mexican Americans," Res. Aging, vol. 33, no. 4, pp. 403-425, 2011.

[29] N. Krause, "Religious Meaning and Subjective Well-Being in Late Life," J. Gerontol., vol. 58, no. 3, pp. 160-170, 2003.

[30] F. J. Seyyed, A. Abraham, and M. Al-hajji, "Seasonality in stock returns and volatility: The Ramadan effect," Res. Int. Bus. Financ., vol. 19, pp. 374-383, 2005.

[31] J. Bialkowski, M. T. Bohl, P. Kaufmann, and T. P. Wisniewski, "Do mutual fund managers exploit the Ramadan anomaly? Evidence from Turkey,” Emerg. Mark. Rev., vol. 15, pp. 211-232, 2013.

[32] H. Chen and R. P. Volpe, "An Analysis of Personal Financial Literacy Among College Students," Financ. Serv. Rev., vol. 7, no. 2, pp. 107-128, 1998.

[33] J. M. Jacobs-lawson and D. A. Hershey, "Influence of future time perspective , financial knowledge , and financial risk tolerance on retirement saving behaviors," Financ. Serv. Rev., vol. 14, pp. 331-344, 2005.

[34] C. A. Robb and D. L. Sharpe, "Effect of Personal Financial Knowledge on College Students ' Credit Card Behavior,” J. Financ. Couns. Plan., no. 205, pp. 25-43, 2009.

[35] C. A. Robb and A. S. Woodyard, "Financial Knowledge and Best Practice Behavior," J. Financ. Couns. Plan., no. 205, pp. 60-70, 2011.

[36] C. A. Robb, "Financial Knowledge and Credit Card Behavior of College Students," J Fam Econ Iss, pp. 
690-698, 2011.

[37] J. L. Parrotta and P. J. Johnson, "The Impact Of Financial Attitudes And Knowledge On Financial Management And Satisfaction Of Recently Married Individuals,” J. Financ. Couns. Plan., vol. 9, no. 2, 1998.

[38] C. Loibl and T. K. Hira, "Self-directed Financial Learning and Financial Satisfaction," J. Financ. Couns. Plan., vol. 16, no. 1, pp. 11-21, 2005.

[39] A. Pellinen, K. Tormakangas, O. Uusitalo, and A. Rajjas, "Measuring the financial capability of investors: A case of the customers of mutual funds in Finland," Int. J. Bank Mark., vol. 20, no. 2, 2011.

[40] B. M. S. Van Praag, "The Welfare Function of Income in Belgium: An Empirical Investigation," Eur. Econ. Rev., 1971.

[41] B. M. S. Van Praag, "The Connexion Between Old and New Approaches To Financial Satisfaction," 2004.

[42] E. Diener and R. B. Diener, "Will money increase subjective well-being?," Soc. Indic. Res., pp. 119$169,2002$.

[43] A. A. Zemtsov and T. Y. Osipova, "Financial Wellbeing as a Type of Human Wellbeing: Theoretical Review," in The European Proceedings of Social \& Behavioral Sciences, 2015.

[44] Z. Bodie, J. Treussard, and P. Willen, "The Theory of Life - Cycle Saving and Investing," 2007.

[45] R. D. A. Parmitasari, "Analysis of Ethics and Investor Behavior and Its Impact on Financial Satisfaction of Capital Market Investors,” Sci. Res. J., vol. VI, no. I, pp. 51-69, 2018.

[46] D. P. Ezama, B. Scandroguo, and B. G. G. De Liano, "Can we predict individual investors ' behavior in stock markets? A psychological approach *," Univ. Psychol., vol. 13, no. 1, pp. 25-35, 2014.

[47] M. Lovric, U. Kaymak, and J. Spronk, “A Conceptual Model of Investor Behavior Milan Lovric , Uzay Kaymak and Jaap Spronk," Rotterdam, 2008.

[48] N. Barberis, A. Shleifer, and R. Vishny, “A model of investor sentiment,” J. financ. econ., vol. 49, pp. 307-343, 1998.

[49] M. Shafi, "Determinants Influencing Individual Investor Behavior In Stock Market: A Cross Country Research Survey," Arab. J. Bus. Manag. Rev., vol. 2, no. 1, pp. 60-71, 2014.

[50] U. Schimmack and E. Diener, "Life-Satisfaction Is a Momentary Judgment and a Stable Personality Characteristic: The Use of Chronically Accessible and Stable Sources," J. Pers., no. June, 2002.

[51] S. Mammen, S. Helmick, and E. Metzen, "Financial well-being and life satisfaction," in Proceedings of the Symposium on Perceived Economic WellBeing, 1983, pp. 8-13.

[52] T. K. Hira and O. M. Mugenda, "Predictors Of Financial Satisfaction: Differences Between Retirees And Non-retirees," J. Financ. Couns. Plan., vol. 9, no. 2, pp. 75-84, 1998.

[53] K. Cramer, H. A. Tuokko, C. A. Mateer, and D. F. Hultsch, "Measuring awareness of financial skills : reliability and validity of a new measure," Aging Ment. Health, vol. 8, no. March, pp. 161-171, 2004.

[54] A. Bandura, Social Learning Theory. New York: General Learning Press, 1971.

[55] A. Bandura, "Model of Causality in Social Learning Theory," in Cognition and Psychotherapy, M. J. Mahoney et al. (eds.), Ed. New York: Plenum Press, 1985, pp. 81-99.

[56] M. A. Hilgert and J. M. Hogarth, "Household Financial Management: The Connection between Knowledge and Behavior," Fed. Reserv. Bull., vol. 106, no. July, 2003.

[57] A. Ferrer-i-carbonell, "Subjective Questions to Measure Welfare and Well Being," 2002.

[58] A. K. Dale, "The association of culture with financial satisfaction," Kansas, 2015.

[59] E. C. Girard and K. Hassan, "Is There a Cost to Faith-Based Investing: Evidence from FTSE Islamic Indices," J. Invest., vol. 17, no. 4, 2008.

[60] A. Z. Arifin, "Influence Factors toward Financial Satisfaction with Financial Behavior as Intervening Variable on Jakarta Area Workforce," Eur. Res. Stud. J., vol. XXI, no. 1, pp. 90-103, 2018.

[61] S. Joo, "Personal Financial Wellness, , (editor JJ Xiao ), Springer, pp: 21-33.," in Handbook of Consumer Finance Research, J. J. Xiao, Ed. Springer, 2008, pp. 21-34.

[62] S. Ali, R. M. Zani, and K. Kasim, "Factors Influencing Investors' Behavior in Islamic Unit Trust: An Application of Theory of Planned Behavior," J. Islam. Econ. Bank. Financ., vol. 10, no. 2, pp. 183-201, 2014. 